\title{
Irrigation's effect and applied selection on the fiber quality of Ethyl MethaneSulfonate (EMS) treated upland cotton (Gossypium hirsutum L.)
}

WITT Travis W. ${ }^{1,2}$, ULLOA Mauricio ${ }^{2 *}$, PELLETIER Mathew G. ${ }^{3}$, MENDU Venugopal ${ }^{1}$ and RITCHIE Glen L. ${ }^{1}$

\begin{abstract}
Background: Producing rainfed cotton (Gossypium hirsutum L.) with high fiber quality has been challenging in the Texas High Plains because of extended periods of insufficient rainfall during sensitive boll developmental stages. Genetic variation created by Ethyl MethaneSulfonate (EMS) mutagen has successfully improved fiber quality of cotton. However, little is known about the effect of water deficit environments on fiber quality. Three EMS treated populations were advanced from the first to the fourth generation (M1 to M4) as bulk harvested populations. In 2014, single-plant divergent selection was applied based on perceived morphological and agronomic differences seen during and at the end of the season.

Results: Analyses from these selections in 2014-2016 showed significant $(P<0.05)$ improvement between and within populations for fiber traits (micronaire, length, strength, uniformity, and elongation) when compared with the original non-treated EMS source; some selections were found to have excellent fiber quality under diverse irrigationregimes.

Conclusions: Some of these selections are being considered for germplasm release and could be useful for improving the fiber quality of cotton under water limited conditions, thereby helping to ensure the long-term survival of the cotton industry on the Texas High Plains.
\end{abstract}

Keywords: Breeding, Drought, EMS, Ethyl MethaneSulfonate, Fiber quality, Selection

\section{Background}

Cotton (G. hirsutum L.) is an important natural fiber, which is estimated to generate over 3.4 billion kilograms of lint annually thereby supporting in excess of US $\$ 25$ billion in products and services in the United States alone (USDA-ERS 2016). Cotton is valued primarily due to its use as a natural fiber product. Fiber quality is vital for creating high valued products and reducing waste during yarn processing and production in textile mills. With world-wide unpredictable rainfall events and declining levels of available ground water to use for irrigation, breeding programs around the world are engaged

\footnotetext{
* Correspondence: Mauricio.ulloa@ars.usda.gov

${ }^{2}$ USDA-ARS, PA, CSRL, Plant Stress and Germplasm Development Research,

Lubbock, TX 79415, USA

Full list of author information is available at the end of the article
}

in developing cotton cultivars/germplasm with drought tolerance, superior yield and fiber quality. Producing rainfed cotton with high fiber quality has traditionally been difficult in the Texas High Plains because of unpredictable rainfall events or extended periods of drought during sensitive production developmental stages. Studies on the impact of irrigation on yield and fiber quality remains inconsistent and the true mechanisms by which fiber development is impacted by drought is not fully understood. Under different irrigation regimes fiber quality's responses are sometimes different from what the conventional wisdom suggests (Bauer et al. 2009; Ritchie et al. 2009; Snowden et al. 2013). The improvement of fiber quality traits such as length, uniformity, strength, elongation, maturity, and fineness, when under water stress or limited irrigation, may be even more

(c) The Author(s). 2018 Open Access This article is distributed under the terms of the Creative Commons Attribution 4.0 International License (http://creativecommons.org/licenses/by/4.0/), which permits unrestricted use, distribution, and reproduction in any medium, provided you give appropriate credit to the original author(s) and the source, provide a link to the Creative Commons license, and indicate if changes were made. The Creative Commons Public Domain Dedication waiver (http://creativecommons.org/publicdomain/zero/1.0/) applies to the data made available in this article, unless otherwise stated. 
complicated than improvement of these complex traits under well-watered conditions (Paterson et al. 2003).

High yielding cotton with superior fiber quality is often grown where water is the limiting factor (Cook and El-Zik 1993). Reduced irrigation has been shown to have a negative impact on the quality of fiber (Pettigrew 2004; Snowden et al. 2013; Feng et al. 2014). However, this impact may be lessened through the identification of more drought tolerant genotypes. Identifying these genotypes may be difficult, because many researchers have suggested that only a small amount of genetic diversity exists in cultivated cotton species (Meredith Jr. 2000; Ulloa et al. 2009; Ulloa 2014; Hinze et al. 2016).

One breeding method that has been used in the improvement of fiber quality involves the use of a mutagen such as Ethyl MethaneSulfonate (EMS) (Auld et al. 2007; Brown et al. 2012; Patel et al. 2014). Previous studies reported that creating genetic diversity with EMS may improve fiber quality under well water conditions or non-stressed environments.

The objective of this study was to measure the impact of limited irrigation conditions on the fiber quality traits of EMS treated cotton populations and to further investigate the possibility to identify superior mutant lines with improved yield and fiber quality traits for public germplasm release. The following sub-objectives were also investigated in this study: a) to determine the effect of multiple irrigation rates and seasons on the fiber quality of EMS treated populations, and b) to identify potential EMS treated novel germplasm with improved fiber quality produced under diverse irrigation regimes.

\section{Results}

In 2014, because too many of the single plant inferior (referring herein as a poor yield and seed performer) selections did not produce enough fiber $(10 \mathrm{~g})$ to be tested by the High-Volume Instrument (HVI), the effect of the different irrigation regimes on the EMS treated populations was evaluated in only the superior (referring herein as an excellent/good yield and seed performer) selections. Ten grams is needed for the proper evaluation of fiber quality traits using the Uster 1000. Evaluation of seed cotton and lint yield data for this study has previously been published (Witt et al. 2018). When the fiber traits (length, strength, micronaire, elongation, and uniformity) were evaluated, the Raider 276 and TTU 774 populations had no significant differences between the different irrigation levels $(232 \mathrm{~mm}$ and $347 \mathrm{~mm})$ for all traits. However, significant differences $(P \leq 0.05)$ were observed within the strength measurement of the Tamcot Sphinx population. Fiber strength ranged from 304 kilonewton meter per kilograms $\left(\mathrm{kN} \cdot \mathrm{m} \cdot \mathrm{kg}^{-1}\right)$ for the high irrigation rate to $295 \mathrm{kN} \cdot \mathrm{m} \cdot \mathrm{kg}^{-1}$ for the low irrigation rate (Table 1 ).

Before 2015 planting season, independently of the fiber quality traits, a decision was made to further evaluate as many selections as possible from the low irrigation rate $(232 \mathrm{~mm})$ from the 2014 divergent selections, and if the seed was unavailable from the low rate to supplement with selections from the high irrigation rate $(347 \mathrm{~mm})$. This decision was also based on the assumption that superior selections under low irrigation already experienced one cycle of drought selection. A total of 146 selections (46 from Raider 276, 50 from TTU 774, and 50 from Tamcot Sphinx) were evaluated under three irrigation rates, within each irrigation rate.

Most of the fiber quality traits evaluated in 2015 from the EMS treated populations were not significantly different from the non-treated EMS or original non-treated EMS source for all three populations under all three irrigation rates. However, fiber uniformity and elongation were greater than or equal to the original non-treated EMS source in all three irrigation rates (data not shown). In the EMS treated populations of Raider 276 and Tamcot Sphinx, fiber strength was also greater than or equal to the original non-treated EMS source in all three irrigation rates. In the EMS treated populations and the controls there was no consistency or observed trend in the response of the fiber quality traits to the different irrigation regimes. However, it was clear that higher variability in response was observed under high irrigation than no irrigation in 2015.

At the end of the 2015 growing season, a reselection for superior yield on either inferior or superior selections was executed based on visual boll-load (open bolls per plants in a research plot) over all three irrigation rates.

Table 1 Fiber quality of superior selections across two irrigation rates at Location 1 (Lubbock, TX) in 2014

\begin{tabular}{|c|c|c|c|c|c|c|c|c|c|c|c|c|c|c|c|c|c|c|}
\hline \multirow[t]{2}{*}{ Population } & \multicolumn{2}{|c|}{ Micronaire } & \multicolumn{2}{|c|}{ Length / mm } & \multicolumn{2}{|c|}{$\begin{array}{l}\text { Strength / } \\
\left(\mathrm{kN} \cdot \mathrm{m} \cdot \mathrm{kg}^{-1}\right)\end{array}$} & \multicolumn{2}{|c|}{ Uniformity / \% } & \multicolumn{2}{|c|}{ Elongation / \% } & \multicolumn{2}{|c|}{$\begin{array}{l}\text { Seed cotton } \\
\text { yield / g } \\
\end{array}$} & \multicolumn{2}{|c|}{ Seed yield / g } & \multicolumn{2}{|c|}{ Lint yield / g } & \multicolumn{2}{|c|}{ Lint / \% } \\
\hline & $\begin{array}{l}\text { High } \\
(347 \\
\mathrm{mm})\end{array}$ & $\begin{array}{l}\text { Low } \\
(232 \\
\mathrm{mm})\end{array}$ & $\begin{array}{l}\text { High } \\
(347 \\
\mathrm{mm})\end{array}$ & $\begin{array}{c}\text { Low } \\
(232 \\
\mathrm{mm})\end{array}$ & $\begin{array}{l}\text { High } \\
(347 \\
\mathrm{mm})\end{array}$ & $\begin{array}{l}\text { Low } \\
(232 \\
\mathrm{mm})\end{array}$ & $\begin{array}{l}\text { High } \\
(347 \\
\mathrm{mm})\end{array}$ & $\begin{array}{l}\text { Low } \\
(232 \\
\mathrm{mm})\end{array}$ & $\begin{array}{l}\text { High } \\
(347 \\
\mathrm{mm})\end{array}$ & $\begin{array}{l}\text { Low } \\
(232 \\
\mathrm{mm})\end{array}$ & $\begin{array}{l}\text { High } \\
(347 \\
\mathrm{mm})\end{array}$ & $\begin{array}{l}\text { Low } \\
(232 \\
\mathrm{mm})\end{array}$ & $\begin{array}{l}\text { High } \\
(347 \\
\mathrm{mm})\end{array}$ & $\begin{array}{l}\text { Low } \\
(232 \\
\mathrm{mm})\end{array}$ & $\begin{array}{l}\text { High } \\
(347 \\
\mathrm{mm})\end{array}$ & $\begin{array}{l}\text { Low } \\
(232 \\
\mathrm{mm})\end{array}$ & $\begin{array}{l}\text { High } \\
(347 \\
\mathrm{mm})\end{array}$ & \\
\hline aider 276 & 4.1 & 4.4 & 29.7 & 29.0 & 309 & 308 & 83 & 83 & 6.4 & 6.6 & 144.3 & 62.6 & 83.9 & 36.1 & 55.1 & 24.3 & 39.5 & 40.0 \\
\hline TTU 774 & 4 & 4 & 30.4 & 29.8 & 346 & 40 & 85 & 84 & 7.1 & 6.9 & 145.7 & 144.7 & 82 & 82 & 55.6 & 56.4 & 39.6 & 40. \\
\hline amcot Sphinx & 4.8 & 4.8 & 27.4 & 27.6 & $304^{*}$ & $295^{*}$ & 83 & 84 & 7.3 & 7.4 & 134.0 & 113.8 & 73.2 & 60.8 & 52.8 & 46.1 & 41.8 & 42.9 \\
\hline
\end{tabular}

Note: Values within a genotype and trait followed by an asterisk are significantly different $(P \leq 0.05)$ 
First a progeny row was evaluated in the no irrigation rate $(0 \mathrm{~mm})$; then the line was confirmed if it also had a superior boll-load in the high $(142 \mathrm{~mm})$ and medium $(71 \mathrm{~mm})$ irrigation rates. This reselection was performed to obtain the best possible lines with yield potential for replicated trials under different irrigation regimes and test sites in 2016, and with potential for a public germplasm release. Below are the 2015 results and comparisons (Tables 2, 3 and 4) from 33 EMS treated re-selections of three populations from the different trait analyses. These 33-selections were also planted for the 2016 season.

In 2015, for the Raider 276 population under the high irrigation rate, there were significant differences $(P \leq 0.05)$ for all fiber traits evaluated (Table 2). The fiber length ranged from $29.8 \mathrm{~mm}$ for T13 to $27.6 \mathrm{~mm}$ for T2. The elongation was highest for T35 at 10.4\% and lowest for $\mathrm{T} 18$ at $6.6 \%$ (data not shown). In the medium irrigation rate, there were no significant differences for all fiber traits evaluated (Table 2). In the no irrigation rate, there were significant differences $(P \leq 0.05)$ for the strength and elongation only (Table 2). The length ranged from 30.1 $\mathrm{mm}$ for T25 to $29.7 \mathrm{~mm}$ for T41. The elongation ranged from $10.2 \%$ for $\mathrm{T} 35$ to $6.6 \%$ for $\mathrm{T} 13$ and T18. Fiber strength and elongation, followed by fiber length were impacted in the high and no irrigation rates, indicating more variability on the response of these traits to water stress.
In 2015, for the TTU 774 population under the high irrigation rate there were significant differences $(P \leq 0.05)$ for micronaire, length, and strength. The length ranged from $30.7 \mathrm{~mm}$ for T82 to $27.1 \mathrm{~mm}$ for T65 (Table 3). In the medium irrigation rate, there were significant differences for the length and strength. The fiber length ranged from $31.1 \mathrm{~mm}$ for T72 to $27.8 \mathrm{~mm}$ for T50 (Table 3). In the no irrigation rate, there were significant differences $(P \leq 0.05)$ for the strength and elongation. The fiber length was highest for T72 at $31.1 \mathrm{~mm}$ and lowest for T50 at $27.8 \mathrm{~mm}$. The elongation ranged from $9.1 \%$ for T58 to $6.9 \%$ for T91 and T18. In all the irrigation rates, TTU 774. EMS treated selections' fiber traits responded to changes in water rates.

In 2015, for the Tamcot Sphinx EMS treated population under the high irrigation rate there were significant differences $(P \leq 0.05)$ for all traits except the uniformity. The fiber length ranged from $31.4 \mathrm{~mm}$ for T163 to $27.9 \mathrm{~mm}$ for T179 (Table 4). The elongation ranged from $9.1 \%$ for $\mathrm{T} 164$ to $7.2 \%$ for $\mathrm{T} 177$ and T188. In the medium irrigation rate, there were no significant differences for any of the fiber quality traits evaluated (Table 4). In the no irrigation rate, there were no significant differences $(P \leq 0.05)$ for any of the fiber quality traits evaluated (Table 4). The length ranged from $27.4 \mathrm{~mm}$ for $\mathrm{T} 180$ to $25.4 \mathrm{~mm}$ for T188.

Table 2 Fiber quality of Raider 276 selections at Lubbock, TX (Location 1) in 2015 under multiple irrigation rates

\begin{tabular}{|c|c|c|c|c|c|c|c|c|c|c|c|c|c|}
\hline \multirow[b]{2}{*}{ Genotype } & \multirow[b]{2}{*}{ Selection } & \multicolumn{4}{|c|}{ No irrigation $(0 \mathrm{~mm})$} & \multicolumn{4}{|c|}{ Medium irrigation (71 mm) } & \multicolumn{4}{|c|}{ High irrigation (142 mm) } \\
\hline & & Micronaire & $\begin{array}{c}\text { Length / } \\
\mathrm{mm}\end{array}$ & $\begin{array}{l}\text { Strength / } \\
\mathrm{kN} \cdot \mathrm{m} \cdot \mathrm{kg}^{-1}\end{array}$ & $\begin{array}{c}\text { Lint } \\
\text { yield / } \\
\mathrm{g}\end{array}$ & Micronaire & $\begin{array}{c}\text { Length / } \\
\mathrm{mm}\end{array}$ & $\begin{array}{l}\text { Strength / } \\
\mathrm{kN} \cdot \mathrm{m} \cdot \mathrm{kg}^{-1}\end{array}$ & $\begin{array}{c}\text { Lint } \\
\text { yield / } \\
\mathrm{g}\end{array}$ & Micronaire & $\begin{array}{c}\text { Length / } \\
\mathrm{mm}\end{array}$ & $\begin{array}{l}\text { Strength / } \\
\mathrm{kN} \cdot \mathrm{m} \cdot \mathrm{kg}^{-1}\end{array}$ & $\begin{array}{c}\text { Lint } \\
\text { yield / } \\
\text { g }\end{array}$ \\
\hline Raider 276 \pm & Control & 4.4 & 28.5 & 307 & 68.0 & 4.8 & 29.3 & 319 & 71.4 & 4.6 & 30.7 & 325 & 83.3 \\
\hline $\mathrm{T} 2$ & Low superior & 4.8 & 29.9 & 343 & 51.4 & 4.9 & 29.0 & 349 & 57.1 & 5.0 & $27.6^{*}$ & 327 & $55.6^{*}$ \\
\hline $\mathrm{T} 4$ & Low superior & 4.6 & 29.9 & 337 & 71.1 & 4.7 & 29.8 & 351 & 72.1 & 4.9 & 28.6 & 330 & 74.6 \\
\hline T10 & Low superior & 4.9 & 29.9 & 345 & 142.6 & 5.0 & 30.2 & 350 & 64.6 & 5.0 & 29.0 & 336 & 76.5 \\
\hline $\mathrm{T} 13$ & High inferior & 4.7 & 29.8 & $320^{*}$ & 71.1 & 4.6 & 30.9 & 354 & 37.6 & 4.8 & 29.8 & 336 & $57.0^{*}$ \\
\hline T18 & High inferior & 4.9 & 29.9 & 331 & 61.0 & 5.0 & 30.0 & 349 & 89.7 & 4.8 & 28.8 & 323 & 82.8 \\
\hline $\mathrm{T} 25$ & Low superior & 4.6 & 30.1 & 358 & 66.3 & 4.8 & 30.2 & 351 & 55.7 & 4.7 & 29.6 & 343 & 75.9 \\
\hline T35 & Low superior & 5.0 & 29.9 & 341 & 77.2 & 4.7 & 30.0 & 346 & 64.2 & $5.2^{*}$ & 28.0 & 336 & 81.5 \\
\hline T38 & High inferior & & & & — & 5.1 & 30.6 & 347 & 73.1 & $5.2^{*}$ & 29.4 & $309^{*}$ & 87.2 \\
\hline T41 & Low superior & 4.9 & 29.7 & 345 & 75.7 & 5.2 & 29.4 & 350 & 79.7 & $5.3^{*}$ & 28.2 & 362 & 90.7 \\
\hline T46 & Low superior & 4.9 & 30.0 & $317 *$ & 66.0 & 4.8 & 30.5 & 349 & 56.5 & $5.1^{*}$ & 28.8 & 320 & 81.1 \\
\hline $\begin{array}{l}\text { EMS } \\
\text { Average }\end{array}$ & & 4.8 & 29.9 & 337 & 74.7 & 4.9 & 30.1 & 350 & 65.0 & 5.0 & 28.8 & 332 & 76.3 \\
\hline $\begin{array}{l}\text { FiberMax } \\
958\end{array}$ & Check & 4.7 & 27.4 & 299 & 67.9 & 4.8 & 28.1 & 288 & 71.0 & 4.6 & 29.2 & 308 & 80.7 \\
\hline Phytogen 72 & Check & 4.7 & 30.0 & 342 & 66.6 & 4.8 & 30.1 & 351 & 58.3 & 4.8 & 29.3 & 339 & 82.8 \\
\hline Average & & 4.7 & 28.7 & 321 & 67.2 & 4.8 & 29.1 & 320 & 64.6 & 4.7 & 29.5 & 324 & 81.8 \\
\hline
\end{tabular}

Note: Values within a column followed by an asterisk are significantly different from the control and check average by Dunnett's test $(P \leq 0.05)$. Only the lines that were also evaluated in 2016 are shown. The non-mutated parent variety is identified by \pm 


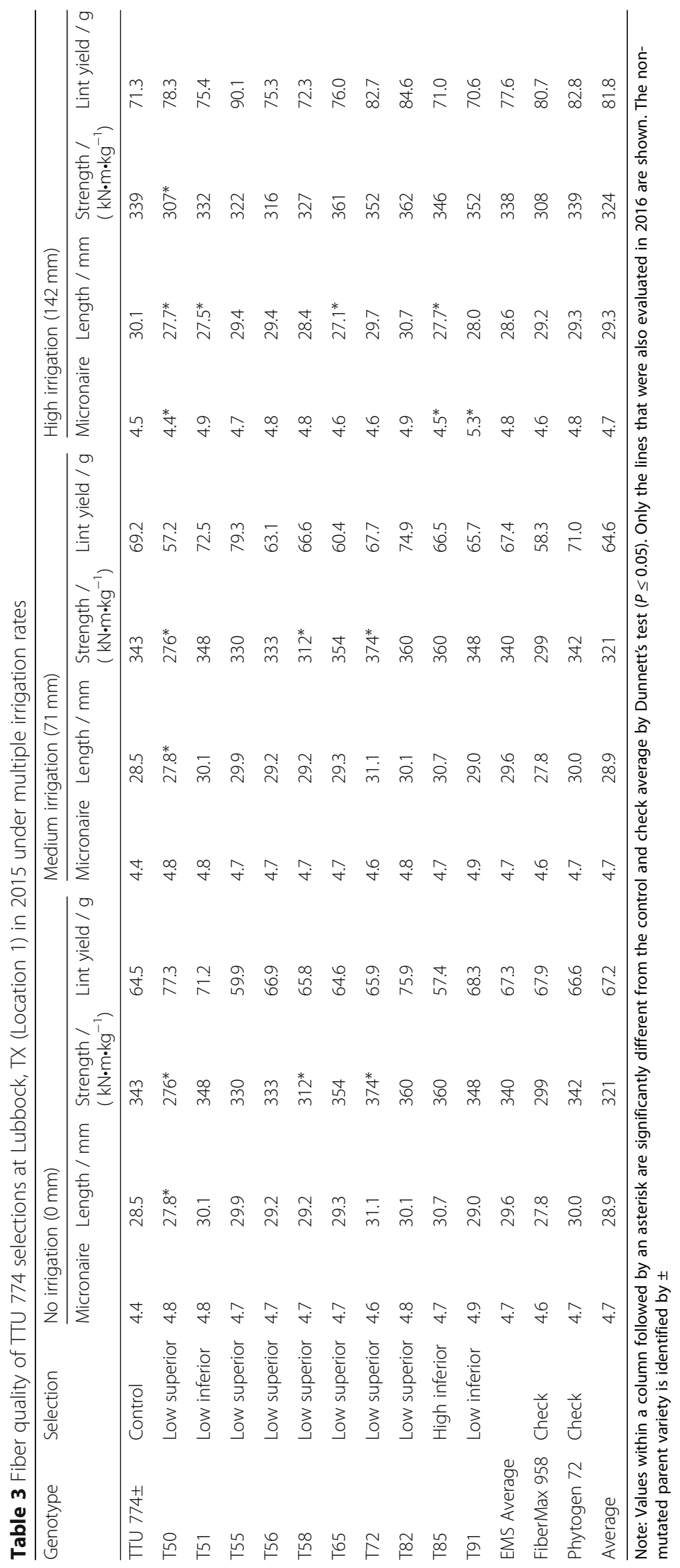


Table 4 Fiber quality of Tamcot Sphinx selections at Lubbock, TX (Location 1) in 2015 under multiple irrigation rates

\begin{tabular}{|c|c|c|c|c|c|c|c|c|c|c|c|c|c|}
\hline \multirow[b]{2}{*}{ Genotype } & \multirow[b]{2}{*}{ Selection } & \multicolumn{4}{|c|}{ No irrigation $(0 \mathrm{~mm})$} & \multicolumn{4}{|c|}{ Medium irrigation $(71 \mathrm{~mm})$} & \multicolumn{4}{|c|}{ High irrigation (142 mm) } \\
\hline & & Micronaire & $\begin{array}{c}\begin{array}{c}\text { Length/ } \\
\mathrm{mm}\end{array} \\
\end{array}$ & $\begin{array}{l}\text { Strength } / \\
\mathrm{kN} \cdot \mathrm{m} \cdot \mathrm{kg}^{-1}\end{array}$ & $\begin{array}{c}\text { Lint } \\
\text { yield / } \\
\mathrm{g}\end{array}$ & Micronaire & 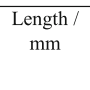 & $\begin{array}{l}\text { Strength / } \\
\mathrm{kN} \cdot \mathrm{m}^{\circ} \mathrm{kg}^{-1}\end{array}$ & $\begin{array}{c}\text { Lint } \\
\text { yield } / \\
\mathrm{g}\end{array}$ & Micronaire & $\begin{array}{c}\text { Length/ } \\
\text { mm }\end{array}$ & $\begin{array}{l}\text { Strength/ } \\
\mathrm{kN} \cdot \mathrm{m} \cdot \mathrm{kg}^{-1}\end{array}$ & $\begin{array}{c}\text { Lint } \\
\text { yield /g }\end{array}$ \\
\hline $\begin{array}{l}\text { Tamcot } \\
\text { Sphinx } \pm\end{array}$ & Control & 4.7 & 27.4 & 303 & 65.7 & 4.8 & 28.5 & 322 & 72.7 & 4.8 & 30.5 & 321 & 81.9 \\
\hline T144 & Low superior & 4.7 & 27.2 & 343 & 77.8 & 4.8 & 29.9 & 348 & 63.4 & $4.4^{*}$ & 29.7 & 342 & 84.9 \\
\hline $\mathrm{T} 150$ & Low inferior & 4.8 & 26.4 & 343 & 61.6 & 4.8 & 29.1 & 320 & 55.3 & $5.3^{*}$ & 28.8 & 339 & 117.1 \\
\hline T151 & Low inferior & 4.8 & 24.4 & 331 & 54.7 & 4.8 & 30.1 & 349 & 97.2 & 5.0 & 28.6 & 341 & 71.9 \\
\hline $\mathrm{T} 152$ & Low superior & 4.7 & 27.2 & 352 & $85.0^{*}$ & 4.8 & 30.6 & 368 & 82.9 & 5.1 & 29.3 & 346 & 66.3 \\
\hline $\mathrm{T} 153$ & Low superior & 4.7 & 27.2 & 350 & 78.2 & 4.9 & 30.3 & 352 & 79.8 & $5.1^{*}$ & 29.6 & 338 & 84.7 \\
\hline $\mathrm{T} 163$ & Low superior & 4.8 & 25.9 & 334 & 71.3 & 4.8 & 29.7 & 332 & 79.6 & $5.3 *$ & $31.4^{*}$ & 357 & 82.9 \\
\hline T164 & Low superior & 4.9 & 27.2 & 345 & 71.3 & 4.9 & 29.9 & 346 & 69.1 & $5.3^{*}$ & 29.1 & 338 & $98.9^{*}$ \\
\hline T169 & Low inferior & 4.8 & 26.2 & 339 & 63.0 & 4.8 & 30.0 & 346 & 74.2 & 4.8 & 29.4 & 338 & 79.1 \\
\hline $\mathrm{T} 177$ & Low inferior & 4.9 & 25.9 & 348 & 62.3 & 4.8 & 30.2 & 359 & 90.9 & 5.0 & 29.1 & 347 & 64.2 \\
\hline T179 & Low superior & 4.8 & 25.9 & 338 & 66.1 & 4.7 & 30.1 & 351 & 102.6 & 5.1 & $27.9^{*}$ & 326 & 84.5 \\
\hline $\mathrm{T} 180$ & Low superior & 4.7 & 27.4 & 345 & 62.4 & 4.7 & 30.6 & 365 & 57.9 & 4.6 & 29.6 & 328 & 78.4 \\
\hline $\mathrm{T} 182$ & Low inferior & 4.7 & 26.7 & 338 & 63.8 & 4.8 & 30.0 & 341 & 67.8 & $4.5^{*}$ & 29.4 & 331 & 68.2 \\
\hline T188 & Low superior & 4.8 & 25.4 & 334 & 61.5 & & & & 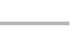 & 4.9 & 28.8 & 331 & 70.5 \\
\hline $\begin{array}{l}\text { EMS } \\
\text { Average }\end{array}$ & & 4.8 & 26.4 & 342 & 67.6 & 4.8 & 30.1 & 349 & 76.7 & 5.0 & 29.3 & 339 & 80.9 \\
\hline FiberMax 958 & Check & 4.6 & 27.8 & 299 & 67.9 & 4.8 & 28.1 & 288 & 58.3 & 4.6 & 27.9 & 309 & 80.7 \\
\hline Phytogen 72 & Check & 4.7 & 30.0 & 342 & 66.6 & 4.8 & 30.1 & 351 & 71.0 & 4.8 & 30.5 & 339 & 82.8 \\
\hline Average & & 4.7 & 28.9 & 321 & 67.3 & 4.8 & 29.1 & 320 & 64.7 & 4.7 & 29.2 & 324 & 81.8 \\
\hline
\end{tabular}

Note: Values within a column followed by an asterisk are significantly different from the control and check average by Dunnett's test $(P \leq 0.05)$. Only the lines that were also evaluated in 2016 are shown. The non-mutated parent variety is identified by \pm

The elongation ranged from $8.5 \%$ for T153 and T164 to $7.0 \%$ for $\mathrm{T} 151$ and T188. In 2015, for the Tamcot Sphinx selections variability in response to irrigation was only observed in the high irrigation rate.

In 2016, the 33 EMS treated re-selections from the three EMS treated populations were evaluated at two geographic locations and two irrigation rates (Tables 5 and 6) to assess the overall selection scheme in this study and to obtain the best possible selections with superior yield potential and fiber quality for a public germplasm release. The EMS treated selections were compared with the non-treated EMS controls, and to FiberMax (FM) 958 and Phytogen 72 commercial cultivar checks. There were significant $(P \leq 0.05)$ genotype by location and genotype by irrigation interactions, so the selections at the high irrigation rate at Location 1 (Lubbock, TX) was evaluated separately from Location 2 (New Deal, TX) to better understand genotypic differences.

When the EMS treated selections were examined in the high irrigation rate $(106 \mathrm{~mm})$ at Location 1 , significant differences $(P \leq 0.05)$ were observed in micronaire, uniformity, and elongation between the Raider 276 line-performers and the original non-treated EMS source (data not shown). The fiber length ranged from
$29.9 \mathrm{~mm}$ for T18 to $26.8 \mathrm{~mm}$ for T35 (Table 5). The elongation ranged from $10.2 \%$ for T35 to $5.4 \%$ for T46. In the no irrigation rate $(0 \mathrm{~mm})$ of Location 1 , significant differences $(P \leq 0.05)$ were observed in micronaire, length, uniformity, and elongation between the Raider 276 selections and the original non-treated EMS source (data not shown). The fiber length was highest for T38 at $28.8 \mathrm{~mm}$ and lowest for T2 at $26.2 \mathrm{~mm}$ (Table 5). For the TTU 774 selections in the high irrigation rate at Location 1, there were significant differences for all the traits evaluated. The fiber length ranged from $31.2 \mathrm{~mm}$ for T72 to $27.3 \mathrm{~mm}$ for T50 (Table 5). For the TTU 774 selections in the no irrigation rate at Location 1, there were significant differences for all the traits evaluated. T72 had the highest fiber length $(29.4 \mathrm{~mm})$ and T58 had the lowest $(25.9 \mathrm{~mm})$. T58 had the highest elongation (9.6\%) and T55 had the lowest (6.5\%). For the Tamcot Sphinx line-performers in the high irrigation rate (106 $\mathrm{mm})$ at Location 1 , there were significant differences $(P \leq 0.05)$ for all the traits evaluated (data not shown). The fiber length ranged from $28.8 \mathrm{~mm}$ for T152 to 24.5 $\mathrm{mm}$ for T150 (Table 5). For the Tamcot Sphinx selections in the no irrigation rate $(0 \mathrm{~mm})$ at Location 1 there were significant differences for all the traits evaluated except uniformity (data not shown). The original 
Table 5 Fiber quality of tetraploid selections at Lubbock, TX (Location 1) in 2016

\begin{tabular}{|c|c|c|c|c|c|c|c|}
\hline \multirow[t]{2}{*}{ Genotype } & \multirow[t]{2}{*}{ Selection } & \multicolumn{3}{|c|}{ No irrigation $(0 \mathrm{~mm})$. } & \multicolumn{3}{|c|}{ High irrigation (106 mm) } \\
\hline & & Micronaire & Length / mm & Strength $/\left(\mathrm{kN} \cdot \mathrm{m} \cdot \mathrm{kg}^{-1}\right)$ & Micronaire & Length / mm & Strength $/\left(\mathrm{kN} \cdot \mathrm{m} \cdot \mathrm{kg}^{-1}\right)$ \\
\hline Raider 276 & Control & $5.4 \mathrm{a}$ & 27.9 a-d & $333 a$ & $5.1 \mathrm{~cd}$ & $29.2 \mathrm{a}$ & $342 \mathrm{a}$ \\
\hline $\mathrm{T} 10$ & Low superior & $5.6 \mathrm{a}$ & $28.2 \mathrm{ab}$ & $344 a$ & $5.4 \mathrm{bc}$ & $28.8 \mathrm{a}$ & $350 \mathrm{a}$ \\
\hline T18 & High inferior & $5.6 \mathrm{a}$ & $28.1 \mathrm{a}-\mathrm{c}$ & $335 a$ & $5.4 \mathrm{bc}$ & $29.9 \mathrm{a}$ & $363 a$ \\
\hline T25 & Low superior & $5.0 \mathrm{c}$ & $28.4 \mathrm{a}$ & 338 a & $4.9 \mathrm{~d}$ & $29.5 \mathrm{a}$ & $322 \mathrm{a}$ \\
\hline T35 & Low superior & $5.5 \mathrm{a}$ & 26.8 de & $326 a$ & $5.8 \mathrm{a}$ & $26.8 b$ & $333 a$ \\
\hline T38 & High inferior & $5.4 \mathrm{ab}$ & $28.8 \mathrm{a}$ & 322 a & $5.2 \mathrm{~b}-\mathrm{d}$ & $29.4 \mathrm{a}$ & $326 a$ \\
\hline EMS Average & & 5.4 & 27.5 & 335 & 5.3 & 28.6 & 339 \\
\hline TTU 774 & Control & $5.4 \mathrm{~b}$ & $27.8 b-d$ & $375 a b$ & $5.3 a b$ & 27.9 de & $378 a b$ \\
\hline T58 & Low superior & $5.2 \mathrm{~cd}$ & $25.9 e$ & $340 c$ & $5.1 \mathrm{~b}-\mathrm{d}$ & $29.5 \mathrm{a}-\mathrm{d}$ & 335 de \\
\hline $\mathrm{T} 72$ & Low superior & $5.2 \mathrm{~cd}$ & $29.4 a$ & $388 a$ & $4.7 \mathrm{f}$ & $31.2 \mathrm{a}$ & $386 a$ \\
\hline T82 & Low superior & $5.3 b-d$ & $28.1 \mathrm{a}-\mathrm{c}$ & $374 a b$ & $5.2 \mathrm{a}-\mathrm{c}$ & 29.2 b-e & $385 a$ \\
\hline T85 & High inferior & 4.9 e & $28.6 \mathrm{ab}$ & $398 a$ & 4.8 ef & 29.8 a-d & $380 \mathrm{ab}$ \\
\hline EMS Average & & 5.3 & 27.6 & 362 & 5.0 & 29.2 & 366 \\
\hline Tamcot Sphinx & Control & 5.5 ef & $27.9 \mathrm{a}$ & $337 a-c$ & $5.3 d$ & $28.6 \mathrm{a}$ & $363 a$ \\
\hline T152 & Low superior & $5.3 \mathrm{~g}$ & $27.3 \mathrm{ab}$ & $357 a$ & $5.2 \mathrm{~d}$ & $28.8 \mathrm{a}$ & $369 a$ \\
\hline T164 & Low superior & $5.8 \mathrm{~b}-\mathrm{d}$ & $24.9 \mathrm{~d}-\mathrm{f}$ & $291 \mathrm{ef}$ & $5.5 \mathrm{bc}$ & $26.5 c$ & $320 c$ \\
\hline T188 & Low superior & $5.7 c-f$ & $25.4 \mathrm{~cd}$ & $315 c-e$ & $5.6 \mathrm{bc}$ & $26.7 c$ & $318 c$ \\
\hline EMS Average & & 5.7 & 25.1 & 316 & 5.5 & 26.5 & 330 \\
\hline FiberMax 958 & Check & 5.7 & 26.7 & 327 & 5.5 & 27.9 & 337 \\
\hline Phytogen 72 & Check & 5.3 & 27.8 & 355 & 5.3 & 29.0 & 358 \\
\hline Average & & 5.5 & 27.3 & 341 & 5.4 & 28.5 & 348 \\
\hline
\end{tabular}

Note: Analyses were performed on all lines grown in 2016 , but only those for release are shown. ${ }^{*}$ Values within column are significantly different at $P \leq 0.05$ within family. Selection column is based on 2014 selection

non-treated EMS source had the highest fiber length $(27.9 \mathrm{~mm})$ and T179 had the lowest $(23.8 \mathrm{~mm})$ (Table 5). T164 and T188 had the highest elongation (10.1\%) and T169 had the lowest (7.2\%).

In 2016, in the high irrigation rate $(106 \mathrm{~mm})$ of Location 2 , there were significant differences $(P \leq 0.05)$ in micronaire, length, and elongation between Raider 276 selections and the original non-treated EMS source (data not shown). The fiber length ranged from $31.9 \mathrm{~mm}$ for T10 and the original non-treated EMS source to 29.1 $\mathrm{mm}$ for T2 (Table 6). In the no irrigation rate $(0 \mathrm{~mm})$ of Location 2, there were significant differences in micronaire and strength. The fiber length was highest for T10 at $29.0 \mathrm{~mm}$ and lowest for T35 at $27.0 \mathrm{~mm}$ (Table 6). For the TTU 774 selections in the high irrigation rate at Location 2 , there were significant differences $(P \leq 0.05)$ for all the traits evaluated. The fiber length ranged from $32.8 \mathrm{~mm}$ for T72 to $29.2 \mathrm{~mm}$ for T91 (Table 6). For the TTU 774 selections in the no irrigation rate $(0 \mathrm{~mm})$ at Location 2 , there were significant differences $(P \leq 0.05)$ for all the traits evaluated except for fiber uniformity (data not shown). T72 had the highest fiber length (30.9 $\mathrm{mm})$ and T50 had the lowest $(26.8 \mathrm{~mm})$ (Table 6). T58 had the highest elongation (9.0\%) and T91 had the lowest (6.4\%). For the Tamcot Sphinx selections in the high irrigation rate at Location 2 , there were significant differences $(P \leq 0.05)$ for all the traits evaluated. The fiber length ranged from $31.5 \mathrm{~mm}$ for T152 to $26.8 \mathrm{~mm}$ for T179 (Table 6). For the Tamcot Sphinx selections in the no irrigation rate $(0 \mathrm{~mm})$ at Location 2 , there were significant differences $(P \leq 0.05)$ for all the traits evaluated. T152 had the highest fiber length $(28.0 \mathrm{~mm})$ and T150 had the lowest $(23.1 \mathrm{~mm})$ (Table 6). T188 had the highest elongation (11.0\%) and $\mathrm{T} 151$ had the lowest (7.7\%).

Although the different selections from the different populations had differing levels of diversity depending on the fiber trait evaluated and the location and environment, some of the populations produced selections with superior fiber quality when compared with the commercial check FM 958. Also, some of the selections had superior fiber quality when compared with the non-mutated or non-treated EMS control-parent. For the Raider 276 population, there was a diverse response of the genotypes to the different irrigation rates for the fiber micronaire, length, strength, and elongation when compared with the original non-treated EMS source. In the TTU 774 population, the fiber length and strength 
Table 6 Fiber quality of tetraploid selections at New Deal, TX (Location 2) in 2016

\begin{tabular}{|c|c|c|c|c|c|c|c|}
\hline \multirow[t]{2}{*}{ Genotype } & \multirow[t]{2}{*}{ Selection } & \multicolumn{3}{|c|}{ No irrigation $(0 \mathrm{~mm})$. } & \multicolumn{3}{|c|}{ High irrigation (106 mm) } \\
\hline & & Micronaire & Length / mm & Strength $/\left(\mathrm{kN} \cdot \mathrm{m} \cdot \mathrm{kg}^{-1}\right)$ & Micronaire & Length / mm & Strength $/\left(\mathrm{kN} \cdot \mathrm{m} \cdot \mathrm{kg}^{-1}\right)$ \\
\hline Raider 276 & Control & 5.3 de & $27.9 a$ & $327 \mathrm{~cd}$ & $5.1 \mathrm{~b}-\mathrm{d}$ & $31.9 a$ & $364 a$ \\
\hline $\mathrm{T} 10$ & Low superior & $5.6 \mathrm{a}-\mathrm{d}$ & $29.0 \mathrm{a}$ & $354 a-c$ & $5.1 \mathrm{~cd}$ & $31.9 \mathrm{a}$ & $360 \mathrm{a}$ \\
\hline T18 & High inferior & 5.3 de & $28.4 \mathrm{a}$ & $355 \mathrm{ab}$ & $5.0 \mathrm{~d}$ & $31.5 \mathrm{ab}$ & $368 a$ \\
\hline T25 & Low superior & $5.2 \mathrm{e}$ & $28.9 \mathrm{a}$ & $345 a-d$ & $4.6 \mathrm{e}$ & $31.4 \mathrm{ab}$ & $373 a$ \\
\hline T35 & Low superior & $5.7 \mathrm{ab}$ & $27.0 \mathrm{a}$ & $338 b-d$ & $5.5 \mathrm{a}$ & $29.6 \mathrm{~cd}$ & $346 a$ \\
\hline T38 & High inferior & $5.4 \mathrm{~b}-\mathrm{d}$ & $28.5 \mathrm{a}$ & $318 d$ & $5.0 \mathrm{~d}$ & 31.7 a & $374 a$ \\
\hline EMS Average & & 5.5 & 28.1 & 343 & 5.1 & 31.0 & 361 \\
\hline TTU 774 & Control & $5.5 \mathrm{~b}$ & 27.3 ef & $359 d-f$ & $5.0 \mathrm{bc}$ & $31.0 \mathrm{bc}$ & $390 \mathrm{~b}-\mathrm{d}$ \\
\hline T58 & Low superior & $5.4 b-d$ & $27.1 \mathrm{ef}$ & $338 \mathrm{f}$ & $5.1 \mathrm{~b}$ & 30.3 b-d & $365 e$ \\
\hline $\mathrm{T} 72$ & Low superior & $5.1 \mathrm{de}$ & 30.9 a & $416 \mathrm{a}$ & $4.7 d$ & $32.8 \mathrm{a}$ & 395 a-d \\
\hline T82 & Low superior & $5.4 \mathrm{bc}$ & $29.4 b c$ & $407 \mathrm{ab}$ & $5.0 \mathrm{bc}$ & $31.8 \mathrm{ab}$ & $416 a$ \\
\hline T85 & High inferior & $5.1 \mathrm{e}$ & $28.6 \mathrm{~cd}$ & $388 \mathrm{bc}$ & $4.8 \mathrm{~cd}$ & $31.6 \mathrm{a}-\mathrm{c}$ & $413 a b$ \\
\hline EMS Average & & 5.3 & 28.3 & 368 & 5.0 & 30.9 & 384 \\
\hline Tamcot Sphinx & Control & $5.6 \mathrm{~d}-\mathrm{f}$ & $26.8 \mathrm{ab}$ & $333 a b$ & $5.1 \mathrm{f}$ & 29.1 b-d & 354 b-d \\
\hline T152 & Low superior & $5.5 \mathrm{ef}$ & $28.0 \mathrm{a}$ & $350 \mathrm{a}$ & $5.1 \mathrm{ef}$ & $31.5 \mathrm{a}$ & $407 a$ \\
\hline T164 & Low superior & $5.8 \mathrm{a}-\mathrm{d}$ & $25.7 b c$ & $316 b c$ & $5.5 \mathrm{a}-\mathrm{d}$ & 29.3 b-d & 336 d-g \\
\hline T188 & Low superior & $5.9 \mathrm{ab}$ & $25.7 b c$ & $323 b$ & $5.6 \mathrm{ab}$ & $29.8 b c$ & $318 \mathrm{~g}$ \\
\hline EMS Average & & 5.7 & 25.6 & 320 & 5.4 & 29.0 & 347 \\
\hline FiberMax 958 & Check & 5.6 & 27.9 & 349 & 5.4 & 30.7 & 367 \\
\hline Phytogen 72 & Check & 5.4 & 27.5 & 350 & 5.2 & 31.2 & 392 \\
\hline Average & & 5.5 & 27.2 & 342 & 5.2 & 30.2 & 364 \\
\hline
\end{tabular}

Note: Analyses were performed on all lines grown in 2016 , but only those for release are shown. ${ }^{*}$ Values within column are significantly different at $P \leq 0.05$ within family. Selection column is based on 2014 selection

showed a variable response to irrigation when compared with the original non-treated EMS source in all irrigation rates. However, the micronaire had a similar response to the different irrigation regimes. In the Tamcot Sphinx population, the number of classes for mean separation for the length, uniformity, strength, and elongation were increased.

In 2016, for the Raider 276 selections, in all irrigation rates and at both locations, the fiber length, strength and elongation had an increase in the number of unique classes for mean separation. In the TTU 774 selections, variability in mean separation was increased for the length and uniformity when compared with the original non-treated EMS source in all irrigation rates and at both locations. In the Tamcot Sphinx population, increased variability in mean separation was seen for all traits when compared with the original non-treated EMS source. Each population had several lines with increased yield and fiber quality when compared with the original non-treated EMS source. However, most selections were only improved in a few traits when compared with the original non-treated EMS source. The diverse responses of yield and fiber quality suggest that EMS treated populations could be used as a genetic source in a breeding program to increase fiber quality or as future germplasm releases.

\section{Discussion}

In this study, the novel genetic variability created by the chemical mutagen Ethyl MethaneSulfonate (EMS) was evaluated to determine the impact of limited irrigation conditions on the fiber quality traits of EMS treated cotton populations and successive selection-procedures, and to further investigate the possibility to identify superior genotypes with improved yield and fiber quality traits under diverse irrigation regimes for public germplasm release. Producing rainfed cotton with high fiber quality has traditionally been difficult in the Texas High Plains because of unpredictable rainfall events or extended periods of drought during sensitive production/ developmental stages. Fiber traits such as micronaire, length, strength and elongation, and seed cotton yield tended to be more impacted by irrigation regime. On average, the fiber length and at some level, fiber strength selections were the most negatively impacted by reduced irrigation or the lowest rates from all populations. Selections were identified with significantly $(P \leq 0.05)$ better fiber quality traits and similar lint yields to the 
commercial control. These lines could be useful for improving the fiber quality of cotton under limited irrigation conditions, benefiting the future cotton production of the Texas High Plains.

Traditionally, cotton is known to suffer from a limited amount of genetic diversity (Meredith Jr. 2000; Hinze et al. 2016). This lack of diversity is predominantly driven by the over use of the same parent or closely related parent material. For example, the Acala germplasm, known for its high quality fiber, had been used in $73 \%$ of the commercial cultivars released between 1970 and 1990 (Bowman et al. 1996). Many times this problem is amplified by the creation of a new cultivar from the reselection of an old or obsolete cultivar (Van Esbroeck and Bowman 1998). Mining the genetic variability from a gene pool or collection, or increasing the diversity of germplasm in a breeding program is one of the most important tasks for a plant breeder (Dudley and Moll 1969; Meredith Jr. 1984; Ulloa 2006; Zeng et al. 2017). This study was not designed to compare the amount of genetic variability created by EMS and other methods such as using parental crosses or hybridizations. However, some comparisons can be made by using observations from past studies evaluating EMS or parental crosses. When compared with the non-treated EMS original source or control, EMS appears to have created some type of variability affecting different fiber traits in different populations besides the effect or impact of irrigation. The fiber quality traits of length, strength, and elongation are believed to be controlled by complete or partial dominance (Verhalen and Murray 1965; Al-Rawi and Kohel 1970). A biparental cross can show very high heritability for fiber traits while a Design II mating can show lower heritability (May and Green 1994; Ulloa 2006). Genetic variability from a biparental cross depends on the general and specific combining abilities of the parents (Gardner and Eberhart 1966; Hinze et al. 2011). To measure this variability, usually, the $F_{1}, F_{2}$, and parents are compared (May and Green 1994; Tang et al. 1996; Ulloa et al. 2010). Like a biparental cross, the most important part of creating variation through EMS is the starting source (parent) that will be treated with the mutagen. Currently, there is no method to measure the variability or genetic diversity created by using a chemical mutagen such as EMS in cotton.

The selection method used in this study was able to capture a superior amount of variation when compared with the original non-treated EMS source for most traits and within most irrigation rates. However, the amount of variation seen differed from year to year. This may be due to several factors. The first is that the inferior/poor selections were not evaluated in 2014, because they produced too little fiber for the HVI to measure. The elimination of these selections from our study reduced the amount of observed diversity in our analyses. The second is that the plants were selected primarily on diversity in yield potential and not on fiber quality. Yield and fiber quality have been shown to be negatively correlated (Miller and Rawlings 1967; Meredith Jr. and Bridge 1971; Culp and Harrell 1973). The third factor is that cotton fiber quality changes within a plant and from different growing environments (temperature, precipitation, etc., ...) (Kelly et al. 2015). The fourth factor is that fiber quality in EMS treated populations has been shown to have a relatively low heritability (Herring et al. 2004). This makes it difficult to separate the effect of the EMS and the effect of the irrigation when evaluating the responses to irrigation in this study. Despite these difficulties, the average value of some traits from the selections were able to be improved in all three EMS treated populations when compared with both the original non-treated EMS source and the commercial check-cultivars.

In a four-year study, the fiber traits that were evaluated fluctuated in their significance (Pettigrew 2004). For example, the fiber strength of the irrigated and non-irrigated plots was significantly different for only two of the 4 years. In this study, some traits occasionally appeared to have better fiber quality in water limited conditions. For example, fiber strength in the EMS treated populations was highest in the medium irrigation rate in 2015. Some selections in some of the EMS treated populations tended to benefit by small deficits in irrigation, increasing the quality of the above fiber traits as shown in the 2015 medium-irrigation regime (some levels of stress) in this study. However, for the commercial checks this was not the case. Other studies also occasionally found better fiber quality in the lower irrigation rate than the high irrigation rate (Pettigrew 2004; Bradow and Davidonis 2010; Karademir et al. 2011). One reason for the increase in fiber quality may be due to fewer bolls being produced and taking resources from the bolls already produced (Bradow and Davidonis 2010). Another reason is because only a minimum number of bolls have been retained; whereas in a higher irrigation rate bolls that do not have enough time to fully develop may still be produced, so fiber quality parameters are lowered (Bradow and Davidonis 2010). In water-stressed and non-stressed plants, the size of the bolls are not different, only the number (Krieg and Sung 1986). Overall, decreased irrigation had a negative impact on the fiber quality of the EMS treated selections, the original non-treated EMS sources, and the commercial checks. The exception to this observation is the medium irrigation rate that had the higher fiber quality than the high and no irrigation rates in 2015. This may indicate that some stresses at the right developmental fiber stage are required to produce cotton with high 
fiber quality on the Texas High Plains. However, additional research is needed to further evaluate the above statement with a diverse germplasm-set, multiple irrigation rates and multiple test environments to determine where this beneficial stress ends.

In this study, there were differences in the performance of the selections from the different EMS treated populations. However, the general trend is that the strength of the Raider 276 population, the strength and elongation of the Tamcot Sphinx population, and the length and elongation of the TTU 774 population were all higher than their original non-treated EMS source. In addition, in non-stressed environments, micronaire, length, and strength were all improved through the use of EMS (Brown et al. 2012).

\section{Conclusion}

This study provides support that EMS seems to have created genetic variability in most traits and most irrigation rates evaluated in this study. This EMS genetic variability is promising for using in a breeding program to improve the fiber quality of cotton. Water stress appears to have a negligible impact on fiber uniformity. However, other fiber traits especially fiber length and strength were impacted by the stress. The effect of EMS on different fiber traits from different populations leads to the necessity to study this further. Additional research is ongoing to examine and validate the contribution of the EMS treatment on selected line-performers by genotyping using single nucleotide polymorphisms (SNPs), that may positively or negatively contribute to the variability found in the fiber properties of these lines. In addition, even though, no significant differences for yield were observed between some selected line-performers and controls or commercial check, several line-performers showed superior fiber quality and superior yield. Some of these selections will be further evaluated as possible germplasm releases. This study increased our understanding of the variability that may be created by EMS in cotton populations and it increased our understanding of the stability of these traits across irrigation rates and locations.

\section{Materials and methods}

\section{Plant material and data collection}

Seed from the following genotypes 'Raider 276' (Texas Tech University PI 645 568) (Auld et al. 2007), 'Tamcot Sphinx' (El-Zik and Thaxton 1996) (Texas A\&M University PI 592 801), and 'TTU 774' (Texas Tech Univ. PI 643 915) (Bechere et al. 2006) were treated with EMS and bulk harvested from the first to the third generation (M1-M3). These genotypes had been treated with EMS using a previously described method (Auld et al. 1998). These genotypes were selected for treatment due to their adaptation to the Texas High Plains, including yield and fiber quality. In 2014, the fourth generation (M4) seeds from these populations were grown at Location 1 [Texas Tech University Quaker Research Farm, Lubbock, TX $\left(33^{\circ}\right.$ $\left.\left.35^{\prime} \mathrm{N}, 101^{\circ} 52^{\prime} \mathrm{W}\right)\right]$. At the end of the season, divergent selection based on morphological and agronomic traits was performed in each population to obtain a diverse panel of individuals with normal distribution of traits. Within each of these three selected populations, 25 superior single plant selections and 25 inferior single plant selections were chosen within each irrigation rate (100 individuals per population) for evaluation in 2015 as progeny rows. All the bolls from each plant were hand harvested to obtain the seed-cotton from the selections. The seed cotton was ginned on 10-saw or 20-saw gin (Compass Systems Model TT510 or TT520, Carmel, IN).

The agronomic traits of seed-cotton yield, lint yield, and lint percent were calculated based on a per plant basis. The fiber was then evaluated by High-volume instrument (HVI) [Uster HVI 1000 using a 1-2-2 protocol for fiber quality measurements (micronaire, length, strength, uniformity, and elongation)] at the Fiber and Biopolymer Research Institute (FBRI), Lubbock, TX. Due to the minimum fiber volume requirements, to process plant samples with HVI (10 g of lint), 42 of the lines could not be evaluated. In addition, 154 selections were also discarded due to a lack of available seed for further evaluation.

In 2015, seeds from three original non-treated EMS (original seed source), two commercial controls FiberMax (FM) 958 and Phytogen 72, and the fifth generation (M5) seeds from 146 selections (46 Raider 276, 50 Tamcot Sphinx, and 50 TTU 774) representing the three selected populations from 2014 were sown at Location 1 in progeny rows. In 2015, based on yield potential and the previous year's fiber quality data, 33 of the 146 line-performers were advanced for further evaluation in the 2016 growing season as line-performers. Reselection was performed for superior morphological and agronomic traits. In 2016, the sixth generation (M6) seeds from the 33 reselections from 2015 and the same five controls were evaluated at Location 1 and Location 2 [Texas Tech University New Deal Research Farm, New Deal, TX $\left.\left(33^{\circ} 43^{\prime} \mathrm{N}, 101^{\circ} 44^{\prime} \mathrm{W}\right)\right]$. In 2014 , the fiber quality traits were evaluated from the total harvested lint of single plants. In 2015, 35 random bolls were harvested from plants within each plot to analyze the fiber quality by HVI at the FBRI. This was done to standardize the amount of fiber evaluated. At the end of the 2016 season, one meter of each plot was harvested to more accurately predict the fiber quality of each plot. Again, this fiber was evaluated by HVI at the FBRI. For consistency 
in naming, the 2014 selection criteria were used to name the genotypes in the subsequent years.

\section{Irrigation \& soil type}

Location 1 has an Acuff loam soil (Fine-loamy, mixed, superactive, thermic Aridic Paleustolls) and Location 2 has a Pullman clay (Fine, mixed, superactive, thermic Torrertic Paleustolls); irrigation was applied once a week using sub-surface drip irrigation with $30 \mathrm{~cm}$ spacing between emitters placed approximately $25 \mathrm{~cm}$ below the soil surface. During the three-year study, different weekly irrigation regimes were applied to research plots, due to rainfall events to ensure differences in plant stress. Each year, two meters of buffer cotton (plots) were placed around each irrigation rate, to prevent one irrigation rate from effecting the plants within the other. In 2014, at Location 1 seeds were sown in single rows within two irrigation rates ( 232 and $347 \mathrm{~mm}$ annually) at a rate of ten seeds per meter for a total of 2290 individual plants, which were used for single plant line-selections (superior and inferior plant selections) from each irrigation rate. In 2015, at Location 1 selections from 2014 were grown within three irrigation rates (0, 71, and $142 \mathrm{~mm}$ annually) in $4.5 \mathrm{~m}$-plots. In 2016, at Location 1 and 2, selected progeny rows were evaluated in $4.5 \mathrm{~m}$-plots with two irrigation rates $(0$ and $106 \mathrm{~mm}$ annually).

\section{Data analysis}

Different experimental designs were used each year to evaluate the different number of selections and seed availability; in 2014, a complete randomized block was used within each irrigation rate with the 25 similar selections used as replications to determine the effect of the divergent selection; in 2015, an augmented design (used for a small amount of seed, (Federer 1956)) was used with controls (3 non-mutant checks and 2 commercial checks) and three blocks; and in 2016, a randomized complete block was used with three replications within each water-rate at each location. Due to the different experimental designs and selections made the 3 years had different statistical analysis. In 2014, the differences between superior line-performers and inferior line-performers for each population were determined using PROC GLIMMIX (Fisher's protected LSD) to distinguish between means (SAS Institute, 2013). In 2015, PROC MIXED with solutions (Dunnett's test) was used for evaluating between mean differences (SAS Institute, 2013). The solutions were determined by using the original non-treated EMS source and commercial controls evaluated as fixed effects and the test lines as random effects. In 2016, the differences between the selections and the original non-treated EMS source were determined using PROC GLIMMIX (Fisher's protected LSD) used to distinguish between the means (SAS Institute, 2013).

\begin{abstract}
Abbreviations
EMS: Ethyl methanesulfonate; FM: FiberMax; HVI: High-Volume Instrument; $\mathrm{kN} \cdot \mathrm{m} \cdot \mathrm{kg}^{-1}$ : Kilonewtons meter per kilogram; M1, M2, etc: The first mutated generation, the second mutated generation, etc; SNP: Single nucleotide polymorphism
\end{abstract}

\section{Acknowledgements}

The authors would also like to thank Dr. Auld DL for providing the EMS treated populations used in this study and students working at Texas Tech University, PSS and USDA-ARS, Lubbock, TX for assisting in collecting data from these populations. Mention of trade names or commercial products in this article is solely for the purpose of providing specific information and does not imply recommendation or endorsement by the U. S. Department of Agriculture. The U. S. Department of Agriculture is an equal opportunity provider and employer.

\section{Funding}

This study was funded by the Ogallala Aquifer Program with a collaborative project between Texas Tech University and USDA-ARS, PA, Cropping System Research Laboratory, Lubbock, TX, and by USDA-ARS (Project 3096-21000019-00-D) (MU)

\section{Availability of data and materials}

No other data related to this study is available at this time.

\section{Authors' contributions}

Witt TW and Ulloa M conceived and designed the research, Witt TW and Ulloa M performed the experiments and prepared the materials, Witt TW and Ulloa M analyzed the data, Witt TW wrote the paper, Ulloa M, Pelletier MG, Mendu $V$, and Ritchie GL revised the manuscript. All authors read and approved the final manuscript.

Ethics approval and consent to participate Not applicable.

Consent for publication

Not applicable.

\section{Competing interests}

The authors declare that they have no competing interests.

\section{Author details}

${ }^{1}$ Plant and Soil Science Department, Texas Tech University, Lubbock, TX 79409-2122, USA. ²USA-ARS, PA, CSRL, Plant Stress and Germplasm Development Research, Lubbock, TX 79415, USA. ${ }^{3}$ USDA-ARS Cotton Production and Processing Research Laboratory, Lubbock, TX 79403, USA.

Received: 23 August 2018 Accepted: 20 November 2018

Published online: 26 December 2018

\section{References}

Al-Rawi KM, Kohel RJ. Gene action in the inheritance of fiber properties in intervarietal diallel crosses of upland cotton, Gossypium hirsutum L. Crop Sci. 1970;10:82-5.

Auld DL, Bechere E, Krifa M, et al. Registration of 'raider 276', a high-yielding, improved-quality upland mutant cotton cultivar. J Plant Regist. 2007;1:115. https://doi.org/10.3198/jpr2007.01.0059crc.

Auld DL, Ethridge MD, Dever JK, Dotray PD. Chemical mutagenesis as a tool in cotton improvement. In: Beltwide cotton production research conferences; 1998. p. 550-1.

Bauer PJ, Foulk JA, Gamble GR, Sadler EJ. A comparison of two cotton cultivars differing in maturity for within-canopy fiber property variation. Crop Sci. 2009:49:651-7. https://doi.org/10.2135/cropsci2008.06.0350.

Bechere E, Auld DL, Cantrell RG, et al. Registration of TTU 0774-3-3 and TTU 08081-6-1 upland cotton germplasm lines with improved fiber length and strength. J Plant Physiol. 2006;1:58-9.

Bowman DT, May OL, Calhoun DS. Genetic base of upland cotton cultivars released between 1970 and 1990. Crop Sci. 1996;35:577-81. 
Bradow JM, Davidonis GH. Effects of environment on fiber quality. In: Stewart JM, Oosterhuis DM, Heitholt JJ, Mauney JR, editors. Physiology of cotton. Heidelberg: Springer; 2010. p. 229-45.

Brown IN, Smith CW, Auld D, et al. Registration of TAM 94L-25-M24, TAM 94L-25M25, and TAM 94L-25-M30 mutant upland cotton germplasm with improved fiber length and strength. J Plant Regist. 2012;6:195. https://doi.org/10.3198/ jpr2011.05.0245crg

Cook CG, El-Zik KM. Fruiting and lint yield of cotton cultivars under irrigated and nonirrigated conditions. F Crop Res. 1993;33:411-21. https://doi.org/10.1016/ 0378-4290(93)90162-G.

Culp TW, Harrell DC. Breeding methods for improving yield and fiber quality of upland cotton (Gossypium hirsutum L.). Crop Sci. 1973;13:686-9. https://doi. org/10.2135/cropsci1973.0011183X001300060030x .

Dudley JW, Moll RH. Interpretation and use of estimates of heritability and genetic variances in plant breeding. Crop Sci. 1969;9:257-62.

El-Zik KM, Thaxton PM. Registration of Tamcot Sphinx. Crop Sci. 1996;36:1074.

Federer WT. Augmented (or hoonuiaku) designs. Hawaii Planter's Rec. 1956;55: 191-208.

Feng L, Mathis G, Ritchie G, et al. Optimizing irrigation and plant density for improved cotton yield and fiber quality. Agron J. 2014;106:1111-8. https:// doi.org/10.2134/agronj13.0503.

Gardner CO, Eberhart SA. Analysis and interpretation of the variety cross diallel and related populations. Biometrics. 1966;22:439-52.

Herring $A D$, Auld DL, Ethridge MD, et al. Inheritance of fiber quality and lint yield in a chemically mutated population of cotton. Euphytica. 2004;136:333-9. https://doi.org/10.1023/B:EUPH.0000032747.97343.54.

Hinze LL, Campbell BT, Kohel RJ. Performance and combining ability in cotton (Gossypium hirsutum L.) populations with diverse parents. Euphytica. 2011; 181:115-25. https://doi.org/10.1007/s10681-011-0442-x.

Hinze LL, Gazave E, Gore MA, et al. Genetic diversity of the two commercial tetraploid cotton species in the Gossypium diversity reference set. J Hered. 2016;107:274-86. https://doi.org/10.1093/jhered/esw004.

Karademir C, Karademir E, Ekinci R, Berekatoğlu K. Yield and fiber quality properties of cotton ( Gossypium hirsutum L.) under water stress and nonstress conditions. Afr J Biotechnol. 2011;10:12575-83. https://doi.org/10.5897/ AJB11.1118.

Kelly B, Abidi N, Ethridge D, Hequet EF. Fiber to fabric. In: Fang DD, Percy RG, editors. Cotton: agrononomy monograph 57. Madison: ASA, CSSA, SSSA; 2015. p. 665-744.

Krieg DR, Sung JFM. Source-sink relations as affected by water stress during boll development. In: Mauney JR, Stewart JM, editors. Cotton physiology. Memphis: The Cotton Foundation; 1986. p. 73-7.

May OL, Green CC. Genetic variation for fiber properties in elite Pee Dee cotton populations. Crop Sci. 1994;34:684-90.

Meredith WR Jr. Quantitative genetics. In: Kohel RJ, Lewis CF, editors. Cotton: agronomy monograph 24. Madison: ASA, CSSA, SSSA; 1984. p. 131-50.

Meredith WR Jr. Cotton yield progress - why has it reached a plateau? Better Crops. 2000;84:2-5.

Meredith WR Jr, Bridge RR. Breakup of linkage blocks in cotton, Gossypium hirsutum L. Crop Sci. 1971;11:695-8. https://doi.org/10.2135/cropsci1971. 0011183 X001100050027X.

Miller PA, Rawlings JO. Breakup of initial linkage blocks through intermating in a cotton breeding population. Crop Sci. 1967;7:199-204.

Patel JD, Wright RJ, Auld D, et al. Alleles conferring improved fiber quality from EMS mutagenesis of elite cotton genotypes. Theor Appl Genet. 2014;127:821-30. https://doi.org/10.1007/s00122-013-2259-6.

Paterson AH, Saranga Y, Menz M, et al. QTL analysis of genotype x environment interactions affecting cotton fiber quality. Theor Appl Genet. 2003;106:38496. https://doi.org/10.1007/s00122-002-1025-y.

Pettigrew WT. Moisture deficit effects on cotton lint yield, yield components, and bol distribution. Agron J. 2004;96:377-83. https://doi.org/10.2134/agronj2004.0377.

Ritchie GL, Whitaker JR, Bednarz CW, Hook JE. Subsurface drip and overhead irrigation: a comparison of plant boll distribution in upland cotton. Agron J. 2009;101:1336-44. https://doi.org/10.2134/agronj2009.0075.

SAS Institute Inc. SAS/STAT ${ }^{\circledR} 13.1$ User's Guide. Cary, NC: SAS Institute Inc; 2013.

Snowden C, Ritchie G, Cave J, et al. Multiple irrigation levels affect boll distribution, yield, and fiber micronaire in cotton. Agron J. 2013;105:1536-44. https://doi.org/10.2134/agronj2013.0084.

Tang B, Jenkins JN, Watson CE, et al. Evaluation of genetic variances, heritabilities, and correlations for yield and fiber traits among cotton $\mathrm{F}_{2}$ hybrid populations. Euphytica. 1996;91:315-22. https://doi.org/10.1007/BF00033093.
Ulloa M. Heritability and correlations of agronomic and fiber traits in an okra-leaf upland cotton population. Crop Sci. 2006;46:1508-14. https://doi.org/10.2135/ cropsci2005.08-0271.

Ulloa M. The diploid D genome cottons (Gossypium spp.) of the New World. In: Abdurakhmonov I. World Cott Germplasm Resour. IntechOpen. 2014. p. 20329. https://doi.org/10.5772/58387

Ulloa M, Percy R, Hutmacher RB, Zhang J. The future of cotton breeding in the Western United States. J Cotton Sci. 2009;13:246-55.

Ulloa M, Wang C, Roberts PA. Gene action analysis by inheritance and quantitative trait loci mapping of resistance to root-knot nematodes in cotton. Plant Breed. 2010;129:541-50. https://doi.org/10.1111/j.1439-0523. 2009.01717.x

USDA-ERS. USDA ERS - Background. 2016. https://www.ers.usda.gov/dataproducts/cotton-wool-and-textile-data/cotton-and-wool-yearbook/. Accessed 9 May 2017.

Van Esbroeck G, Bowman DT. Cotton germplasm diversity and its importance to cultivar development. J Cotton Sci. 1998;2:121-9.

Verhalen L, Murray J. A diallel analysis of several fiber property traits in upland cotton ( Gossypium hirsutum L.). Crop Sci. 1965;7:501-5.

Witt TW, Ulloa M, Pelletier MG, et al. Exploring ethyl methanesulfonate (EMS) treated cotton (Gossypium hirsutum L.) to improve drought tolerance. Euphytica. 2018;214:123. https://doi.org/10.1007/s10681-018-2206-3.

Zeng L, Wu J, Bechere E. Comparative genetic analysis of lint yield and fiber quality among single, three-way, and double crosses in upland cotton. Crop Sci. 2017;57:192. https://doi.org/10.2135/cropsci2016.06.0499 .
Ready to submit your research? Choose BMC and benefit from:

- fast, convenient online submission

- thorough peer review by experienced researchers in your field

- rapid publication on acceptance

- support for research data, including large and complex data types

- gold Open Access which fosters wider collaboration and increased citations

- maximum visibility for your research: over $100 \mathrm{M}$ website views per year

At BMC, research is always in progress.

Learn more biomedcentral.com/submissions 